\title{
Recent Advances in Conservation of Plant Genetic Resources
}

\author{
Chandrakant Singh ${ }^{1 *}$, Poornima Rail ${ }^{2}$ and Rajkumar BK ${ }^{3}$ \\ ${ }^{1}$ ARS, Junagadh Agricultural University, India \\ ${ }^{2}$ Research Associate, NRM Division, India \\ ${ }^{3}$ ARS, Main Cotton Research Station, India
}

Submission: May 10, 2017; Published: June 05, 2017

"Corresponding author: Chandrakant Singh, ARS, Junagadh Agricultural University (JAU), Junagadh, Gujarat, India, Email: chandrakant.singh07@gmail.com,

\section{Mini Review}

The conservation of plant genetic resources is an important issue concerning the human population worldwide. Conservation of plant genetic resources ensures maintenance of agro biodiversity. Plant genetic resources for food and agriculture are the basis of global food security. They comprise diversity of genetic material contained in traditional varieties, modern Cultivars, crop wild relatives and other wild species. Genetic diversity provides farmers and plant breeders with options to develop, through selection and breeding, new and more productive crops, that are resistant to virulent pests and diseases and adapted to changing environments. The anthropogenic pressure, the introduction of alien species, as well as domesticated species and chronic weed infestation have dramatic effects on plant diversity, which is reflected in an increase in the number of threatened species. The reasons for this loss are many and include deforestation, developmental activities such as hydroelectric projects, road laying, urbanization and changes in agricultural practices, and finally modern agriculture and introduction of new and uniform varieties. Urbanization and changing life styles, globalization and market economies are also contributing indirectly to the loss of diversity, particularly of minor and neglected crops. Such reductions have serious implications for food security in the long term.

The concept of germplasm conservation demands that collection methods initially capture maximum variation and subsequently, conservation and regeneration techniques minimize losses through time [1]. To this effect, plant genetic resources (PGR) conservation activities comprise of collecting, conservation and management, identification of potentially valuable material by characterization, and evaluation for subsequent use. Plant genetic resources conservation can be carried out either in the natural habitats of species' populations (in situ) or outside them (ex situ) $[2,3]$. Ex situ plant genetic resources conservation can be carried out in an efficient and economical way by seed conservation, in seed banks. Seeds of most crops can be stored for long periods under low relative humidity and low temperature conditions. However, seed storage is not feasible in some cases. Seeds of some species are recalcitrant or intermediate, i.e. they cannot stand desiccation below a relatively high critical water content value $(10-12 \%$ or $20 \%$ fresh weight basis, respectively, Hong et al. [4] and cold storage without losing viability [5,6].

In the mid seventies, the use of in vitro culture was pointed out as a feasible alternative for genetic conservation of plants for which seed banking was not possible [7]. In vitro culture does not only provide a method for clonal propagation and safe exchange of plant material but it can also be used for medium-term germplasm conservation. This is achieved by slowing growth, thereby extending the intervals between subcultures [8]. In vitro storage, based on slow growth techniques, is routinely applied to a range of crops as medium term storage [9]. However, concern can be raised on the genetic stability of cultures in the long term (somaclonal variation, Larkin \& Scowcroft [10] and on the possible losses due to contamination.

Cryopreservation is, so far, the only viable procedure for longterm germplasm conservation of vegetatively propagated species and, therefore, can be used for base collections. Cryopreservation implies the conservation of plant propagules at very low temperatures (below $-150{ }^{\circ} \mathrm{C}$ ), thus ensuring that all metabolic processes stop. In this way, subcultures are not required and the threat of somaclonal variation is reduced. Liquid nitrogen (-196 ${ }^{\circ} \mathrm{C}$ ) is usually used as refrigerant, although freezers with working temperatures of $-150{ }^{\circ} \mathrm{C}$ are now available. Cryopreserved material requires a limited space. However, power or liquid nitrogen supply must be guaranteed. 
Advances in biotechnology, especially in the area of in vitro culture techniques and molecular biology provide some important. Moreover, various bio-techniques are not only offer the possibilities of faster multiplication of clones of endangered plant species for conservation of genotypes, but also conserve genetic material, provide the power of modification at genetic level by changing their expression level [11]. Biotechnological methods are reliable and can provide continuously safe, higher quality natural products for food, pharmaceuticals and cosmetic industries; similarly, they are applicable in preserving biodiversity in several ways [12,13]. Several biotechnological approaches are important factors to conserve, analyze and detect genetic diversity of rare and endangered plants such as different molecular marker techniques starting from biochemical, physiological and DNA based markers [14].

\section{References}

1. Astley D (1992) Preservation of genetic diversity and accession integrity. Field Crops Res 29(3): 205-224.

2. Frankel OH, Hawkes JG (1975) Crop genetic resources for today and tomorrow. Cambridge University Press, Cambridge, UK.

3. IriondoJM (2001) Conservación de recursos fitogené-ticos. In: GonzálezAndrés F, Pita Villamil JM (Eds.), Conservación y caracterización de recursosfitogenéticos Publicaciones. INEA, Valladolid, Spain, pp. 13-31.

4. Hong TD, Linington S, Ellis RH (1996) Seed storage behaviour: a compendium. Handbooks for genebanks: No. 4. IPGRI, Rome, Italy, p. 101

5. King MW, Roberts EH (1980) Maintenance of recalcitrant seeds in storage. In: Chin HF, Roberts EH (Eds.), Recalcitrant crop seeds. Tropical Press SDN. BDH, Kuala Lumpur, Malaysia, pp. 53-89.
6. Berjak P, Pammenter NW (1997) Progress in the understanding and manipulation of desiccation-sensitive (recalcitrant) seeds. In: Ellis RH, Black M, Murdoch AJ, Hong TD (Eds.), Basic and applied aspects of seedbiology. Kluwer Academic Publishers, Dordrecht, Netherlands, pp. 689-703.

7. Henshaw GG (1975) Technical aspects of tissue culture storage for genetic conservation. In: Frankel OH, Hawkes JG (Eds.), Crop genetic resources for today and tomorrow. Cambridge University Press, UK, pp. 349-358.

8. Dodds JH (1991) In vitro methods for conservation inplant genetic resources. Chapman and Hall, London, p. 247.

9. Ashmore SE (1997) Status report on the development and application of in vitro techniques for the conservation anduse of plant genetic resources. IPGRI, Rome, Italy, p. 67.

10. Larkin PJ, Scowcroft WR (1981) Somaclonal variation-a novel source of variability from cell cultures forplant improvement. Theor Appl Genet 60(4): 197-214.

11. Verpoorte R, Memelink J (2002) Engineering secondary metabolite production in plants. Current Opinion of Biotechnology 13(2): 181187.

12. Nalawade SM, Sagare AP, Lee CY, Kao CL, Tsay HS (2003) Studies on tissue culture of Chinese medicinal plant resourcesin Taiwan and their sustainable utilization. Botanical Bulletin of Academia Sinica 44: 79-98.

13. Julsing K, Matthys K, Wim JQ Oliver K (2007) The engineering of medicinal plants: prospects and limitations of medicinal plant biotechnology. In: Kayser O, Wim JQ (Eds.), Medicinal Plant Biotechnology: From Basic Research to Industrial Application. WILEYVCH Verlag GmbH \& Co. KGaA-Weinheim, Germany, pp. 3-8.

14. Khan S, Al-Qurainy F, Mohammad N (2012) Biotechnological approaches for conservation and improvement of rare and endangered plants of Saudi Arabia. Saudi Journal of Biological Sciences 19(1): 1-11.

\section{Your next submission with Juniper Publishers will reach you the below assets}

- Quality Editorial service

- Swift Peer Review

- Reprints availability

- E-prints Service

- Manuscript Podcast for convenient understanding

- Global attainment for your research

- Manuscript accessibility in different formats

( Pdf, E-pub, Full Text, Audio)

- Unceasing customer service

Track the below URL for one-step submission https://juniperpublishers.com/online-submission.php 